\title{
Effects of azathioprine and infliximab on mesenchymal stem cells derived from the bone marrow of rats in vitro
}

\author{
HUA-RONG HUANG ${ }^{1}$, HUI ZAN ${ }^{2}$, YING LIN ${ }^{2}$ and YING-QIANG ZHONG ${ }^{2}$ \\ Departments of ${ }^{1}$ Pediatrics and ${ }^{2}$ Gastroenterology and Hepatology, Sun Yat-sen Memorial Hospital, \\ Sun Yat-sen University, Guangzhou, Guangdong 510120, P.R. China
}

Received May 30, 2013; Accepted January 14, 2014

DOI: $10.3892 / \mathrm{mmr} .2014 .1905$

\begin{abstract}
Mesenchymal stem cell (MSC) transplantation has been demonstrated to be promising in the treatment of inflammatory bowel disease (IBD). Azathioprine (AZA) is widely used in IBD patients. Infliximab, as a representative of biological therapy for IBD, is important in the treatment regimen. In the present study we investigated the effects of AZA and infliximab on the cell proliferation, cell cycle and apoptosis of the MSCs derived from the bone marrow of Sprague-Dawley (SD) rats in vitro in order to provide preliminary data for optimizing the treatment of IBD. MSCs derived from the bone marrow of rats were either cultured in various concentrations of AZA- or infliximab-supplemented medium for 24, 48 and $72 \mathrm{~h}$, respectively. The growth curves of MSCs were obtained. The apoptosis and the cell cycle of the MSCs were analyzed by flow cytometry. AZA decreased the proliferation of MSCs by $66 \%$ and increased apoptosis at $0.20 \mathrm{mg} / \mathrm{ml}$ for $72 \mathrm{~h}$ $(\mathrm{P}<0.05)$. The percentage of necrotic cells increased markedly in MSCs treated with $0.30 \mathrm{mg} / \mathrm{ml}$ AZA for $72 \mathrm{~h}(\mathrm{P}<0.05)$. As the exposure time increased, the percentage of MSCs in phase G0-G1 increased and that in phase S decreased in AZA groups exceeding $0.20 \mathrm{mg} / \mathrm{ml}(\mathrm{P}<0.05)$. However, infliximab had a minimal impact on the cell proliferation, apoptosis and cell cycle of the MSCs. AZA was able to inhibit cell proliferation and induce apoptosis of the MSCs in vitro. Infliximab did not affect the cell proliferation, apoptosis and cell cycle of the MSCs derived from rats.
\end{abstract}

\section{Introduction}

Mesenchymal stem cells (MSCs) are multipotent stromal cells that can differentiate into a variety of cell types (1) and exert immunomodulatory functions (2). In recent years, studies have

Correspondence to: Dr Ying-Qiang Zhong or Dr Ying Lin, Department of Gastroenterology and Hepatology, Sun Yat-sen Memorial Hospital, Sun Yat-sen University, 107 West Yanjiang Road, Guangzhou, Guangdong 510120, P.R. China

E-mail: zhongyingqiang@21cn.com

E-mail: linwy@mail.sysu.edu.cn

Key words: azathioprine, infliximab, mesenchymal stem cell, rat demonstrated that MSCs are promising for therapeutic use in inflammatory bowel disease (IBD) (3-5). Azathioprine (AZA) is a purine analog immunosuppressive drug. It is used to treat a vast array of autoimmune diseases, including rheumatoid arthritis, IBD, multiple sclerosis and autoimmune hepatitis (6-10). Its active metabolite, 6-mercaptopurine hampers DNA synthesis and inhibits the proliferation of fast-growing cells, including T lymphocytes (11). The use of AZA and 6-mercaptopurine has been the mainstay of long-term therapy for the majority of IBD patients for numerous years. Their role as steroid sparing agents and in the maintenance of remission is well recognized particularly in those with recommitting recurrence $(12,13)$. An in vivo study indicated that IBD patients treated with AZA have more apoptotic lamina propria mononuclear cells compared with the untreated controls (11). As certain IBD patients may be eligible for MSC transplantation, we examined if the ongoing treatment with AZA will affect the cell proliferation, cell cycle and apoptosis of MSCs.

Infliximab is a human-mouse chimeric monoclonal antibody against tumor necrosis factor- $\alpha(\mathrm{TNF}-\alpha)$ that is used in a variety of autoimmune diseases, including psoriasis, rheumatoid arthritis, Crohn's disease, ulcerative colitis and ankylosing spondylitis (14-17). It functions primarily by binding to TNF- $\alpha$ and prevents it from binding to its receptor. However, its potent anti-inflammatory effect has been demonstrated to function through causing programmed cell death of activated $\mathrm{T}$ lymphocytes, an important cell type mediating inflammation in Crohn's disease (18). The inflamed tissue often releases TNF- $\alpha$ (19), which stimulates the adherence of MSCs to the endothelium and attracts the homing of MSCs to injured sites (20). Nevertheless, there was only limited information available concerning the interaction between the monoclonal anti-TNF- $\alpha$ antibody, infliximab and MSCs (21).

In the present study, we investigated the effects of various concentrations of AZA and infliximab on the cell proliferation, cell cycle and apoptosis of the MSCs derived from the bone marrow of Sprague-Dawley (SD) rats in vitro, in order to provide the preliminary data for optimizing the microenvironment of patients with IBD for the potential use of MSC transplantation.

\section{Materials and methods}

Reagents.Thelow-glucoseDulbecco'smodifiedEagle's medium (DMEM) and $0.25 \%$ trypsin-ethylenediaminetetraacetic acid 
(EDTA) was purchased from Invitrogen Life Technologies (Guangzhou, Guangdong, China). The fetal bovine serum (FBS) was purchased from Hangzhou Sijiqing Biological Engineering Materials Company (Hangzhou, Zhejiang, China). The monoclonal fluorescein isothiocyanate (FITC) anti-rat CD29 Armenian hamster immunoglobulin G (IgG) and FITC anti-rat CD45 mouse IgG were purchased from BioLegend (San Diego, CA, USA). The monoclonal FITC anti-rat CD34 mouse IgG and FITC anti-rat CD44 mouse IgG were purchased from Santa Cruz Biotechnology, Inc. (Santa Cruz, CA, USA). AZA was purchased from Shanghai Pharmaceuticals (Shanghai, China). Infliximab was purchased from Janssen Pharmaceuticals (Janssen Cilag AG, Baar, Switzerland).

Ethics statement. SD rats with specific pathogen-free grade were provided by the Animal Center of Sun Yat-sen University (Guangzhou, Guangdong, China). All experiments were conducted in accordance with the institutional guidelines of Sun Yat-sen University for the care and use of experimental animals.

Preparation and culture of MSCs from the bone marrow of rats. MSCs were obtained from the bone marrow of 3-week-old SD rats. Following euthanasia, whole bone marrow was flushed with DMEM from the tibia and femur of the SD rat. The marrow was pooled and collected in fresh tubes. The marrow suspension was then centrifuged at $157 \mathrm{x} g$ for $10 \mathrm{~min}$. The supernatant was removed and the pellet was resuspended with low-glucose DMEM containing 10\% FBS. Cells were plated in a $25 \mathrm{~cm}^{2}$ flask and incubated in a humidified atmosphere with $5 \% \mathrm{CO}_{2}$ at $37^{\circ} \mathrm{C}$. The medium was changed after 2 days and the nonadherent cells were removed. The medium was then changed every 3 days. When the cells were at $80-90 \%$ confluence, the adherent cells were detached with $0.25 \%$ trypsin EDTA and replated at a 1:2 ratio. The cells were further purified with passages.

The MSCs at passage 4 were trypsinized and harvested. The cells were washed with phosphate-buffered saline (PBS) twice and $1 \times 10^{5}$ cells were used to identify the surface markers. The antibodies against CD29 (0.2 $\mu \mathrm{g} / 10^{5}$ cells), CD34 (0.5 $\mu \mathrm{g} / 10^{5}$ cells $)$, CD44 (0.5 $\mu \mathrm{g} / 10^{5}$ cells) and CD45 $\left(0.2 \mu \mathrm{g} / 10^{5}\right.$ cells) were incubated with the MSCs for $20 \mathrm{~min}$ at room temperature followed by flow cytometry (Becton-Dickinson, Franklin Lakes, NJ, USA).

To evaluate the effects of AZA and infliximab on the MSCs derived from the bone marrow of SD rats, the MSCs at passage 4 were used. The cells were grown in various concentrations of AZA-supplemented $(0,0.05,0.10,0.20$ and $0.30 \mathrm{mg} / \mathrm{ml})$ or infliximab-supplemented $(0,0.10,0.20,0.30$ and $0.40 \mathrm{mg} / \mathrm{ml}$ ) DMEM with $10 \% \mathrm{FBS}$, respectively. The MSCs were incubated in a humidified atmosphere with $5 \%$ $\mathrm{CO}_{2}$ at $37^{\circ} \mathrm{C}$.

Cell proliferation assay. The MSCs at passage 4 were cultured with AZA- or infliximab-supplemented DMEM as described above in 6-well culture dishes with $5 \times 10^{4}$ cells/well for three replicate wells for each treatment and each day. The cells were trypsinized and counted every $24 \mathrm{~h}$ for eight consecutive days, respectively. The growth curves of the MSCs from each group were obtained from three independent experiments.
Table I. Effects of AZA on the growth of MSCs (cell count, $\mathrm{x} 10^{4} ; \mathrm{n}=3$ ).

\begin{tabular}{lccc}
\hline Group & Day 1 & Day 2 & Day 3 \\
\hline A & $7.80 \pm 0.18$ & $8.20 \pm 0.23$ & $15.88 \pm 0.51$ \\
B & $7.63 \pm 0.07$ & $8.64 \pm 0.47$ & $13.45 \pm 0.47$ \\
C & $6.90 \pm 0.09$ & $8.50 \pm 0.37$ & $12.66 \pm 0.20$ \\
D & $6.53 \pm 0.39$ & $8.29 \pm 0.06$ & $5.58 \pm 0.12^{\text {a }}$ \\
E & $6.81 \pm 0.03$ & $8.69 \pm 0.36$ & $5.12 \pm 0.10^{\mathrm{a}}$ \\
\hline
\end{tabular}

${ }^{\mathrm{a}} \mathrm{P}<0.05$, compared with group $\mathrm{A}$ at the indicated time. Group $\mathrm{A}$, $0 \mathrm{mg} / \mathrm{ml} \mathrm{AZA}$; group B, $0.05 \mathrm{mg} / \mathrm{ml} \mathrm{AZA}$, group C, $0.10 \mathrm{mg} / \mathrm{ml}$ AZA; group D, $0.20 \mathrm{mg} / \mathrm{ml} \mathrm{AZA;} \mathrm{and} \mathrm{group} \mathrm{E,} 0.30 \mathrm{mg} / \mathrm{ml} \mathrm{AZA}$. AZA, azathioprine; MSCs, mesenchymal stem cells; $n$, number of repeated experiments.

Cell cycle and apoptosis analysis. The MSCs at passage 4 were plated at 6 -well culture dishes with $2 \times 10^{5}$ cells/well for three replicate wells of each group. When the cells were at $70-80 \%$ confluence, the low-glucose DMEM with 10\% FBS was replaced by AZA- $(0,0.05,0.10,0.20$ and $0.30 \mathrm{mg} / \mathrm{ml})$ or infliximab-supplemented $(0,0.10,0.20,0.30$ and $0.40 \mathrm{mg} / \mathrm{ml})$ DMEM with $10 \% \mathrm{FBS}$, respectively. Cell cycle and apoptosis analysis was performed at 24, 48 and $72 \mathrm{~h}$ using flow cytometry, respectively. The data were obtained from three independent experiments.

For cell cycle analysis, $5 \times 10^{5}$ MSCs were fixed with $70 \%$ ethanol overnight at $-20^{\circ} \mathrm{C}$ and washed twice with PBS. For each reaction, the cells were incubated with $50 \mu \mathrm{g}$ of RNase (Sigma-Aldrich, St. Louis, MO, USA) and $9 \mu \mathrm{g}$ of propidium iodide (Invitrogen Life Technologies, Carlsbad, CA, USA) for $30 \mathrm{~min}$ at $4^{\circ} \mathrm{C}$ in the dark. Cell cycle analysis was then performed using a FACSCalibur flow cytometer (Becton-Dickinson).

To identify the apoptotic MSCs, $1 \times 10^{5}$ cells were harvested and washed with PBS followed by incubation with $5 \mu 1$ Annexin V conjugated to FITC 488 (Molecular Probes, Eugene, OR, USA) and $0.2 \mu \mathrm{g}$ of propidium iodide (Invitrogen Life Technologies, Carlsbad, CA, USA) for $15 \mathrm{~min}$ at room temperature in the dark. Flow cytometry analysis was carried out using a FACSCalibur flow cytometer (Becton-Dickinson).

Statistical analysis. Values are presented as the mean \pm standard deviation. Comparisons of the means between two groups were performed using the Student's t-test. Comparisons of the means among multiple groups were performed using one-way ANOVA. $\mathrm{P}<0.05$ was considered to indicate a statistically significant difference.

\section{Results}

Morphological features of MSCs derived from the bone marrow of SD rats. The primary culture of MSCs was obtained as described. A small fraction of cells from the marrow suspension attached and grew as fibroblastic cells that developed into visible symmetric colonies at $\sim 3$ days after initial plating (Fig. 1A). The hematopoietic stem cells and nonadherent cells were removed with changes of medium. The attached 
A

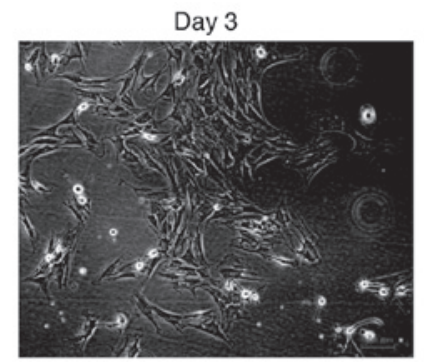

B

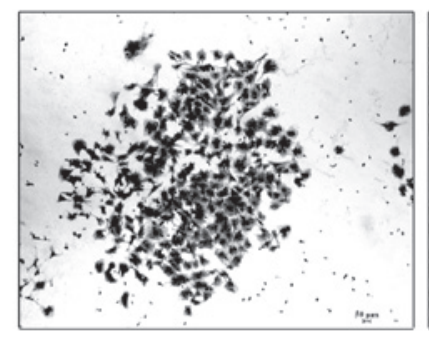

Day 5
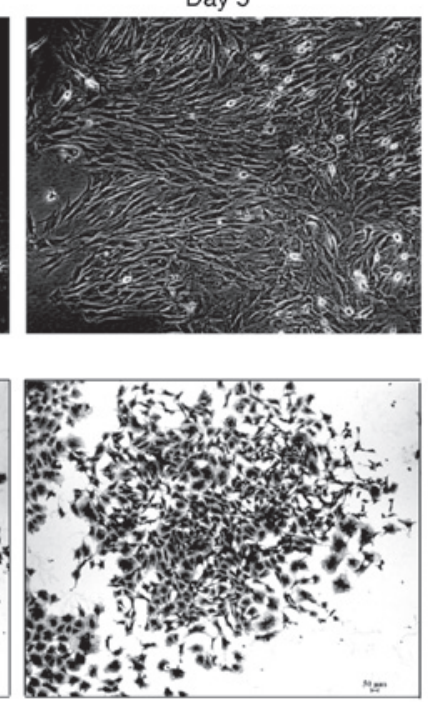

Day 7
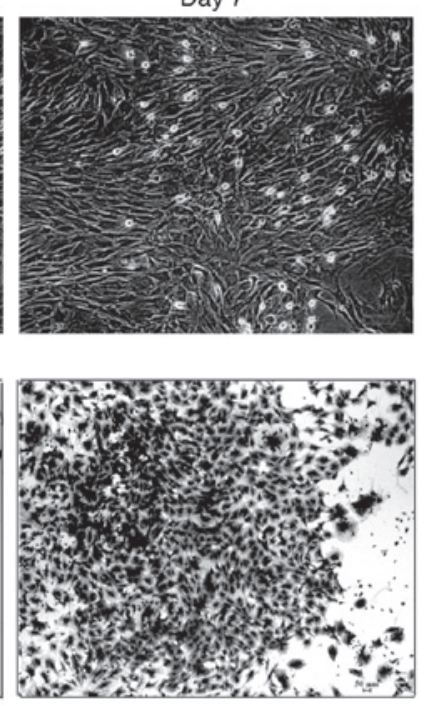

$\mathbf{C}$
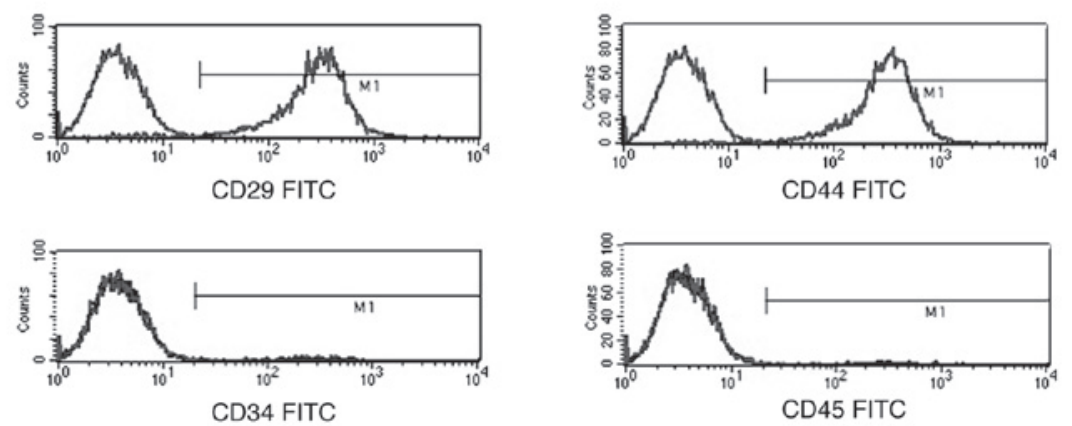

Figure 1. Characteristics of MSCs derived from the bone marrow of Sprague-Dawley rats. (A) Morphology of the primary culture of MSCs using phase contrast microscopy (Leica MPS-30; Leica Camera AG, Solms, Germany; magnification, x100). (B) Features of the primary culture of MSCs stained with methyl violet using light microscopy (Nikon, Tokyo, Japan; magnification, x40). (C) Detection of the surface markers (CD29, CD44, CD34 and CD45) on the MSCs derived from the bone marrow of rats by flow cytometry. MSCs, mesenchymal stem cells.

cells dispersed widely and appeared as small cell bodies with few long and thin cell processes. The cell body contained a large and round nucleus with a prominent nucleolus (Fig. 1A and B). The cells were detached with $0.25 \%$ trypsin EDTA at $\sim 10-12$ days after initial plating. The cells at passage 2 attached within $48 \mathrm{~h}$ and demonstrated long fusiform. The cells grew vigorously and demonstrated a 'swirling growth' pattern. Homogeneity was attained following 3 passages.

Immunophenotyping of the MSCs. The MSCs at passage 4 were used to identify the surface markers, including CD29, CD34, CD44 and CD45. Flow cytometry analysis indicated that $98.25 \pm 0.58 \%$ of the cells were CD29 positive, $98.97 \pm 0.53 \%$ were CD44 positive, only $1.11 \pm 0.34 \%$ of these were CD34 positive and $0.99 \pm 0.53 \%$ were CD45 positive (Fig. 1C). We considered the isolated cells to be bone marrow-derived MSCs (BMSCs) from SD rats.

Effects of AZA and infliximab on the morphology of BMSCs from $S D$ rats. The MSCs at passage 4 were grown in various concentrations of AZA- or infliximab-supplemented medium, respectively. On day 3 , a decreased number and diminished size of the BMSC colonies were observed in those cultured in 0.20 and $0.30 \mathrm{mg} / \mathrm{ml} \mathrm{AZA} \mathrm{supplemented} \mathrm{medium} \mathrm{(Fig.} \mathrm{2D).} \mathrm{The}$ BMSCs became thinner and smaller while cultured in the high
AZA concentration $(0.20$ and $0.30 \mathrm{mg} / \mathrm{ml})$ medium compared with those in the low AZA concentration $(0.05$ and $0.10 \mathrm{mg} /$ $\mathrm{ml}$ ) medium. However, the number and the morphology of the BMSC colonies in various concentrations of infliximab were very similar to those in the control medium on day 3 (Fig. 2E) through to day 7 (data not shown).

Effects of AZA and infliximab on the proliferation of BMSCs from $S D$ rats. As demonstrated in Fig. 2A, the BMSCs grew in the exponential phase from day 3 to day 6 in the blank control medium $(0 \mathrm{mg} / \mathrm{ml} \mathrm{AZA})$, however, they reached the plateau phase following day 6 . Although the proliferation of the BMSCs cultured in 0.05 and $0.10 \mathrm{mg} / \mathrm{ml} \mathrm{AZA-supplemented}$ medium was inhibited compared with that in the blank control medium on day 3 , the difference was not statistically significant $(\mathrm{P}>0.05$; Table I). While the AZA concentration was increased to 0.20 and $0.30 \mathrm{mg} / \mathrm{ml}$, the proliferation of the BMSCs was inhibited by $66 \%$ and $67 \%$ compared with that in the blank control medium on day 3 , respectively $(\mathrm{P}<0.05$; Fig. 2B and Table I). Nevertheless, the proliferation of BMSCs was not significantly affected by infliximab for up to 8 days in the testing range of concentrations (Fig. 2C and Table II).

Effects of AZA and infliximab on apoptosis in BMSCs from SD rats. At $24 \mathrm{~h}$ of AZA treatment, no significant difference in the 
Table II. Effects of infliximab on the growth of MSCs (cell count, $x 10^{4} ; n=3$ ).

\begin{tabular}{|c|c|c|c|c|c|c|c|c|}
\hline Group & Day 1 & Day 2 & Day 3 & Day 4 & Day 5 & Day 6 & Day 7 & Day 8 \\
\hline A & $7.80 \pm 0.18$ & $8.20 \pm 0.23$ & $15.88 \pm 0.51$ & $29.87 \pm 0.23$ & $47.83 \pm 0.27$ & $50.60 \pm 0.53$ & $52.96 \pm 0.65$ & $53.37 \pm 0.55$ \\
\hline B & $7.12 \pm 0.20$ & $7.41 \pm 0.38$ & $14.46 \pm 0.22$ & $29.67 \pm 0.37$ & $46.56 \pm 0.33$ & $49.95 \pm 0.03$ & $52.26 \pm 0.06$ & $53.27 \pm 0.21$ \\
\hline $\mathrm{C}$ & $7.37 \pm 0.22$ & $7.50 \pm 0.38$ & $14.67 \pm 0.26$ & $29.68 \pm 0.26$ & $46.75 \pm 0.24$ & $49.49 \pm 0.31$ & $52.71 \pm 0.20$ & $54.05 \pm 0.58$ \\
\hline $\mathrm{D}$ & $7.34 \pm 0.18$ & $7.99 \pm 0.90$ & $14.32 \pm 0.16$ & $29.10 \pm 0.09$ & $46.08 \pm 0.04$ & $49.19 \pm 0.03$ & $52.22 \pm 0.06$ & $53.47 \pm 0.26$ \\
\hline $\mathrm{E}$ & $7.49 \pm 0.32$ & $7.89 \pm 0.06$ & $14.86 \pm 0.06$ & $29.42 \pm 0.49$ & $46.27 \pm 0.26$ & $49.42 \pm 0.39$ & $52.52 \pm 0.40$ & $53.08 \pm 0.06$ \\
\hline
\end{tabular}

Group A, $0 \mathrm{mg} / \mathrm{ml}$ infliximab; group B, $0.10 \mathrm{mg} / \mathrm{ml}$ infliximab; group C, $0.20 \mathrm{mg} / \mathrm{ml}$ infliximab; group D, $0.30 \mathrm{mg} / \mathrm{ml}$ infliximab; and group E, $0.40 \mathrm{mg} / \mathrm{ml}$ infliximab. MSCs, mesenchymal stem cells; $\mathrm{n}$, number of repeated experiments.
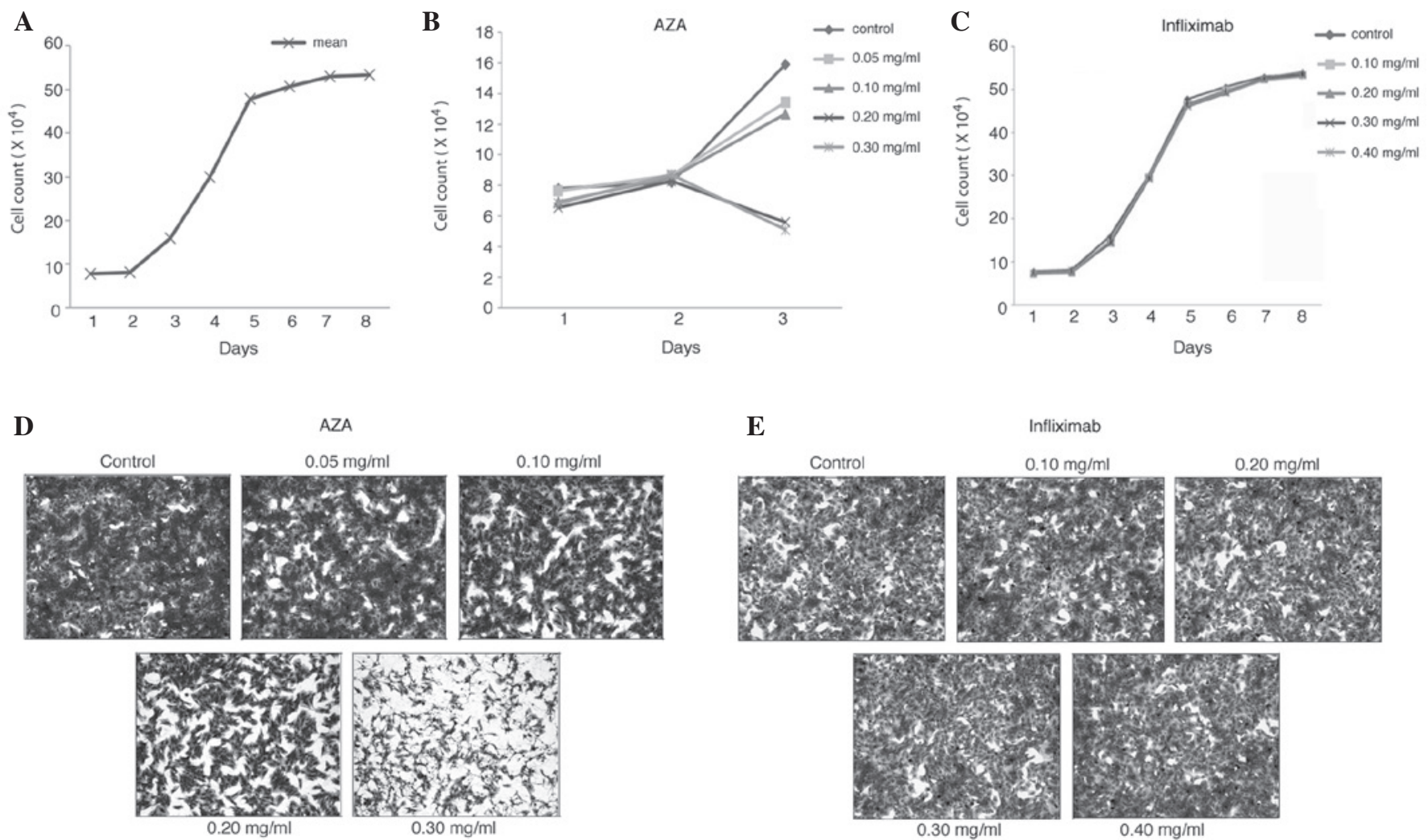

Figure 2. Effects of AZA and infliximab on the proliferation of MSCs derived from the bone marrow of Sprague-Dawley rats. (A) Growth curve of the MSCs at passage 4 without treatment. (B) Growth curve of the MSCs at passage 4 with AZA treatment at various concentrations. (C) Growth curve of the MSCs at passage 4 with infliximab treatment at various concentrations. The data were obtained from three independent experiments. (D) Morphology of the MSCs treated with AZA at various concentrations for $72 \mathrm{~h}$ (stained with methyl violet, magnification, $\mathrm{x} 40$ ). (E) The morphology of the MSCs treated with infliximab at various concentrations for $72 \mathrm{~h}$ (stained with methyl violet, magnification, x40). AZA, azathioprine; MSCs, mesenchymal stem cells.

apoptotic rate was observed across all groups of AZA-treated BMSCs (P>0.05; Table III). However, the number of the apoptotic BMSCs increased significantly at 48 and $72 \mathrm{~h}$ in the $0.20 \mathrm{mg} / \mathrm{ml}$ AZA group compared with the blank control group $(\mathrm{P}<0.05$; Table III). In the $0.30 \mathrm{mg} / \mathrm{ml}$ AZA group, the number of apoptotic BMSCs increased at $48 \mathrm{~h}$, however decreased at $72 \mathrm{~h}$ due to necrosis of the cells $(\mathrm{P}<0.05$; Fig. 3 and Table III). In all groups of the infliximab-treated BMSCs, the apoptotic rates were not statistically different from that of the blank control group on the respective days ( $\mathrm{P}>0.05$; Table IV).

Effect of AZA and infliximab on the cell cycle in BMSCs from $S D$ rats. At 24 h of AZA treatment, no significant effect of AZA on the cell cycle was observed in all groups of the AZA-treated BMSCs ( $\mathrm{P}>0.05$; Table III). At $48 \mathrm{~h}$, the percentage of BMSCs in the G0-G1 phase increased and that in the $\mathrm{S}$ phase reduced in the $0.30 \mathrm{mg} / \mathrm{ml}$ AZA group compared with the blank control group $(\mathrm{P}<0.05$; Table III). At $72 \mathrm{~h}$, the percentage of cells in the G0-G1 phase increased and that in the $\mathrm{S}$ phase reduced in the 0.20 and $0.30 \mathrm{mg} / \mathrm{ml}$ AZA-treated group compared with the blank control group, respectively ( $\mathrm{P}<0.05$; Fig. 4 and Table III). The percentage of BMSCs in the G2-M phase also significantly decreased in the $0.30 \mathrm{mg} / \mathrm{ml}$ AZA-supplemented group at $72 \mathrm{~h}$ ( $\mathrm{P}<0.05$; Fig. 4 and Table III). On the other hand, infliximab did not affect the cell cycle distribution of BMSCs on the respective days compared with the blank control group (Table IV). 
Table III. Effects of AZA on apoptosis and the cell cycle of MSCs $(\%, n=3)$.

\begin{tabular}{|c|c|c|c|c|c|c|}
\hline Group & Time (h) & Apoptosis & Necrosis & G0-G1 & G2-M & $\mathrm{S}$ \\
\hline \multirow[t]{3}{*}{ A } & 24 & $3.80 \pm 0.41$ & $1.64 \pm 0.22$ & $91.63 \pm 0.61$ & $6.30 \pm 0.44$ & $2.07 \pm 0.42$ \\
\hline & 48 & $1.79 \pm 0.91$ & $3.95 \pm 0.77$ & $86.53 \pm 0.66$ & $9.51 \pm 0.67$ & $3.95 \pm 0.29$ \\
\hline & 72 & $3.53 \pm 0.39$ & $5.37 \pm 0.88$ & $74.34 \pm 4.20$ & $15.11 \pm 4.69$ & $10.56 \pm 0.49$ \\
\hline \multirow[t]{3}{*}{ B } & 24 & $3.74 \pm 0.83$ & $1.71 \pm 0.47$ & $90.85 \pm 1.28$ & $7.25 \pm 0.86$ & $1.91 \pm 0.43$ \\
\hline & 48 & $2.42 \pm 0.96$ & $3.70 \pm 0.82$ & $86.99 \pm 0.60$ & $9.31 \pm 0.33$ & $3.83 \pm 0.58$ \\
\hline & 72 & $4.08 \pm 3.13$ & $5.80 \pm 0.21$ & $74.04 \pm 3.47$ & $15.28 \pm 3.03$ & $10.67 \pm 0.47$ \\
\hline \multirow[t]{3}{*}{$\mathrm{C}$} & 24 & $4.78 \pm 1.01$ & $1.79 \pm 0.74$ & $91.97 \pm 1.50$ & $6.09 \pm 0.76$ & $1.94 \pm 0.78$ \\
\hline & 48 & $2.46 \pm 0.43$ & $3.85 \pm 0.32$ & $86.63 \pm 0.51$ & $8.86 \pm 1.54$ & $4.21 \pm 1.18$ \\
\hline & 72 & $3.74 \pm 1.08$ & $5.04 \pm 0.26$ & $74.26 \pm 3.43$ & $14.46 \pm 3.23$ & $11.28 \pm 0.26$ \\
\hline \multirow[t]{3}{*}{$\mathrm{D}$} & 24 & $4.10 \pm 1.57$ & $1.87 \pm 0.67$ & $91.04 \pm 1.39$ & $7.03 \pm 1.32$ & $1.93 \pm 0.10$ \\
\hline & 48 & $4.68 \pm 1.15^{\mathrm{a}}$ & $3.29 \pm 0.68$ & $87.90 \pm 0.51$ & $9.34 \pm 0.37$ & $4.03 \pm 0.35$ \\
\hline & 72 & $11.27 \pm 1.96^{\mathrm{a}}$ & $5.74 \pm 0.441$ & $88.16 \pm 0.33^{\mathrm{a}}$ & $10.27 \pm 0.82$ & $1.57 \pm 0.51^{\mathrm{a}}$ \\
\hline \multirow[t]{3}{*}{$\mathrm{E}$} & 24 & $4.55 \pm 1.97$ & $1.73 \pm 0.63$ & $90.36 \pm 1.63$ & $7.58 \pm 1.22$ & $2.06 \pm 0.49$ \\
\hline & 48 & $5.09 \pm 0.71^{\mathrm{a}}$ & $3.40 \pm 0.68$ & $88.90 \pm 0.72^{\mathrm{a}}$ & $8.60 \pm 0.30$ & $2.50 \pm 0.51^{\mathrm{a}}$ \\
\hline & 72 & $1.67 \pm 0.68^{\mathrm{a}}$ & $14.58 \pm 0.51^{\mathrm{a}}$ & $92.94 \pm 1.26^{\mathrm{a}}$ & $6.31 \pm 0.86^{\mathrm{a}}$ & $0.75 \pm 0.24^{\mathrm{a}}$ \\
\hline
\end{tabular}

${ }^{a} \mathrm{P}<0.05$ compared with group A at the indicated time. Group A, $0 \mathrm{mg} / \mathrm{ml} \mathrm{AZA}$; group B, $0.05 \mathrm{mg} / \mathrm{ml} \mathrm{AZA;} \mathrm{group} \mathrm{C,} 0.10 \mathrm{mg} / \mathrm{ml} \mathrm{AZA;} \mathrm{group}$ $\mathrm{D}, 0.20 \mathrm{mg} / \mathrm{ml}$ AZA; and group E, $0.30 \mathrm{mg} / \mathrm{ml}$ AZA. AZA, azathioprine; MSCs, mesenchymal stem cells; $\mathrm{n}$, number of repeated experiments.
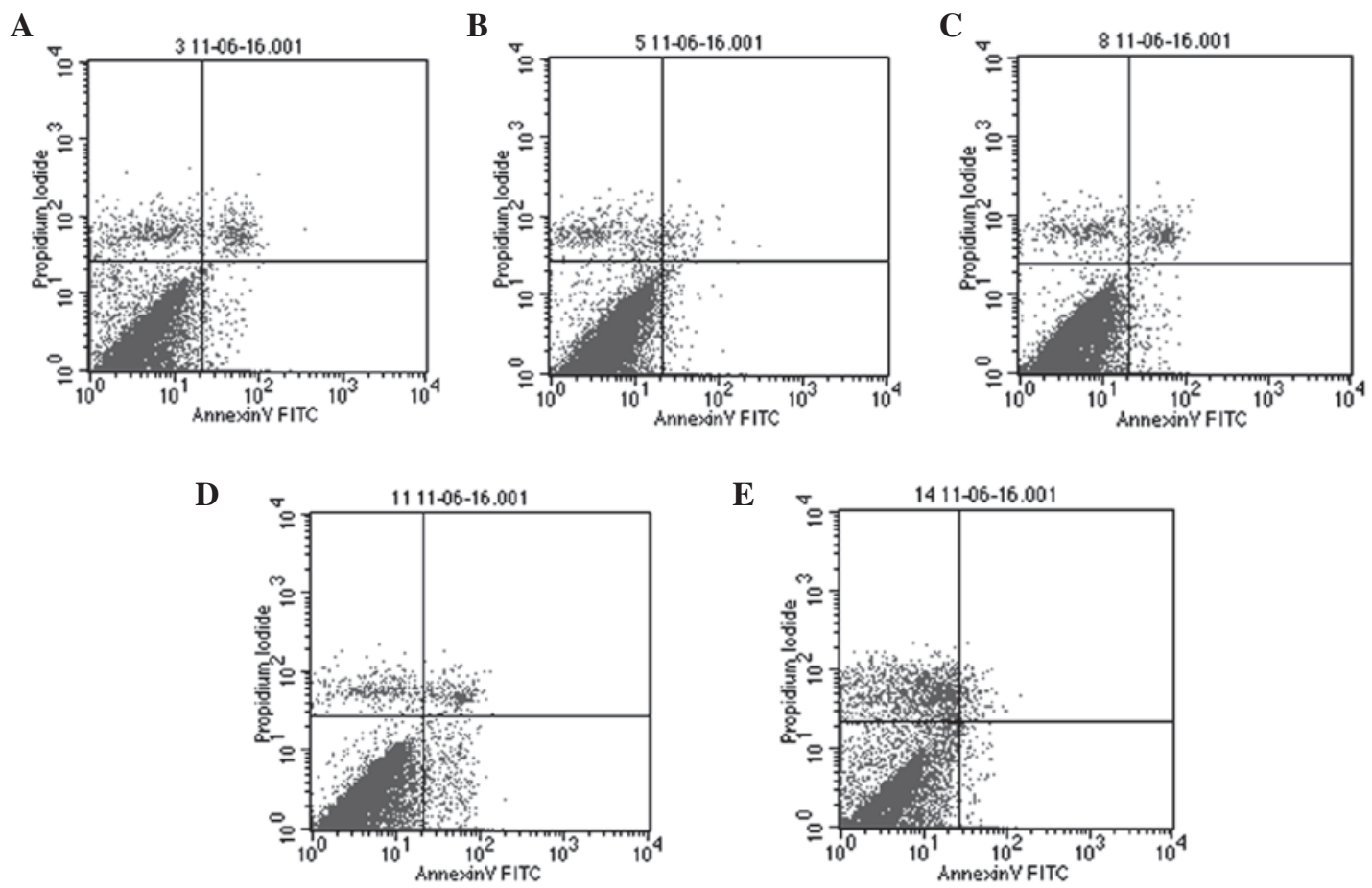

Figure 3. Effects of AZA on the apoptosis of MSCs derived from the bone marrow of Sprague-Dawley rats. The MSCs at passage 4 were treated with AZA at various concentrations for $72 \mathrm{~h}$. The apoptosis was measured by Annexin $\mathrm{V}$ and propidium iodide staining and flow cytometry analysis. (A) Blank control. (B) Treated with $0.05 \mathrm{mg} / \mathrm{ml}$ AZA. (C) Treated with $0.10 \mathrm{mg} / \mathrm{ml}$ AZA. (D) Treated with $0.20 \mathrm{mg} / \mathrm{ml}$ AZA. (E) Treated with 0.30 mg/ml AZA. AZA, azathioprine; MSCs, mesenchymal stem cells.

\section{Discussion}

It is considered that IBD is associated with genetic, immunological, infectious and psychological factors. IBD patients suffer a long term and recurrent course of the disease, which significantly affects their quality of life and occasionally leads to a poor prognosis. The conventional medication for IBD includes aminosalicylates, corticosteroids and immunosuppressants. However, these medications are not able to alter the natural history of IBD and may add up to insurmountable side effects with long-term use. In recent years, stem cell transplantation has become a promising strategy for the treatment of IBD $(4,5)$. MSCs are able to colonize at the intestinal mucosa and differentiate into fibroblasts, myofibroblasts and epithelial 
Table IV. Effects of infliximab on the apoptosis and cell cycle of MSCs (\%, n=3).

\begin{tabular}{|c|c|c|c|c|c|}
\hline Group & Time (day) & Apoptosis & G0-G1 & G2-M & S \\
\hline \multirow[t]{3}{*}{ A } & 1 & $2.82 \pm 0.56$ & $91.60 \pm 0.09$ & $5.73 \pm 0.35$ & $2.68 \pm 0.37$ \\
\hline & 3 & $3.22 \pm 0.75$ & $74.50 \pm 3.28$ & $15.22 \pm 2.87$ & $10.28 \pm 0.72$ \\
\hline & 7 & $5.25 \pm 0.52$ & $93.47 \pm 0.09$ & $4.86 \pm 0.41$ & $1.67 \pm 0.34$ \\
\hline \multirow[t]{3}{*}{ B } & 1 & $2.37 \pm 0.51$ & $92.34 \pm 0.29$ & $5.57 \pm 0.19$ & $2.09 \pm 0.43$ \\
\hline & 3 & $3.63 \pm 1.86$ & $74.57 \pm 4.06$ & $15.81 \pm 3.66$ & $9.61 \pm 0.41$ \\
\hline & 7 & $5.11 \pm 0.23$ & $94.08 \pm 0.62$ & $4.17 \pm 0.28$ & $1.75 \pm 0.23$ \\
\hline \multirow[t]{3}{*}{$\mathrm{C}$} & 1 & $2.85 \pm 0.85$ & $91.90 \pm 1.00$ & $5.24 \pm 0.05$ & $2.51 \pm 0.46$ \\
\hline & 3 & $2.66 \pm 0.77$ & $74.42 \pm 4.59$ & $14.42 \pm 3.07$ & $11.16 \pm 1.60$ \\
\hline & 7 & $5.03 \pm 0.35$ & $94.29 \pm 0.62$ & $4.16 \pm 0.40$ & $1.55 \pm 0.31$ \\
\hline \multirow[t]{3}{*}{ D } & 1 & $3.08 \pm 0.73$ & $91.66 \pm 1.11$ & $5.34 \pm 0.53$ & $2.99 \pm 0.43$ \\
\hline & 3 & $2.65 \pm 0.64$ & $79.34 \pm 1.70$ & $11.06 \pm 1.20$ & $9.60 \pm 1.59$ \\
\hline & 7 & $4.87 \pm 0.50$ & $93.36 \pm 0.81$ & $4.75 \pm 0.37$ & $1.88 \pm 0.72$ \\
\hline \multirow[t]{3}{*}{ E } & 1 & $2.64 \pm 1.42$ & $91.93 \pm 0.68$ & $5.20 \pm 0.29$ & $2.61 \pm 0.28$ \\
\hline & 3 & $3.18 \pm 1.03$ & $72.00 \pm 3.97$ & $12.64 \pm 1.30$ & $10.18 \pm 2.88$ \\
\hline & 7 & $5.01 \pm 0.42$ & $93.81 \pm 0.79$ & $4.53 \pm 0.37$ & $1.65 \pm 0.36$ \\
\hline
\end{tabular}

Group A infliximab, $0 \mathrm{mg} / \mathrm{ml}$; group B infliximab, $0.10 \mathrm{mg} / \mathrm{ml}$; group C infliximab, $0.20 \mathrm{mg} / \mathrm{ml}$; group D infliximab, $0.30 \mathrm{mg} / \mathrm{ml}$; and group E infliximab, $0.40 \mathrm{mg} / \mathrm{ml}$. MSCs, mesenchymal stem cells; $\mathrm{n}$, number of repeated experiments.
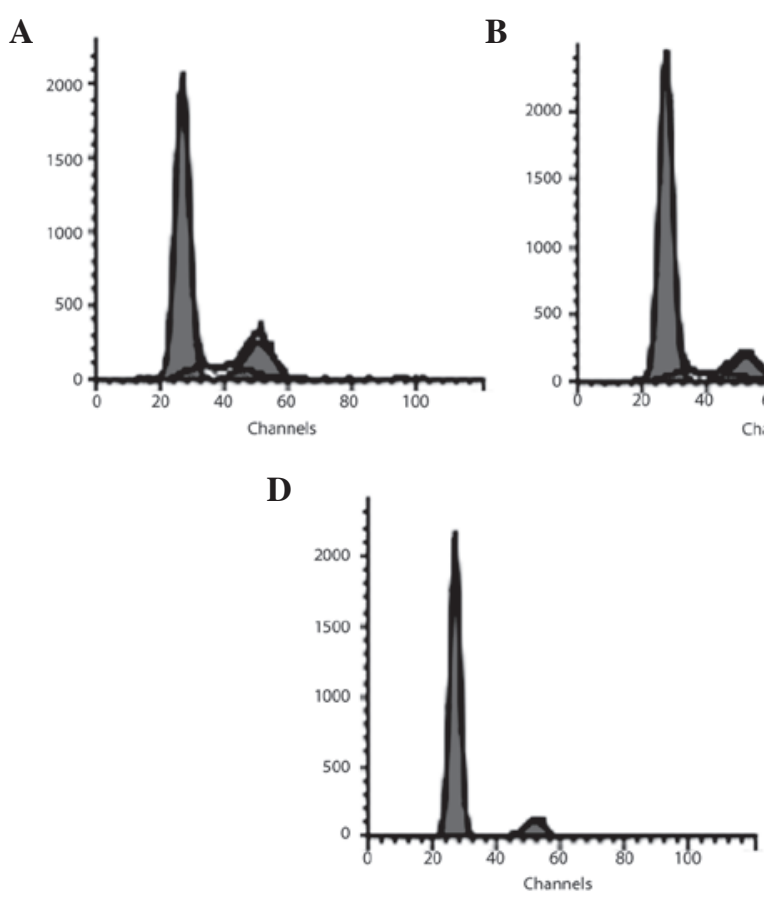
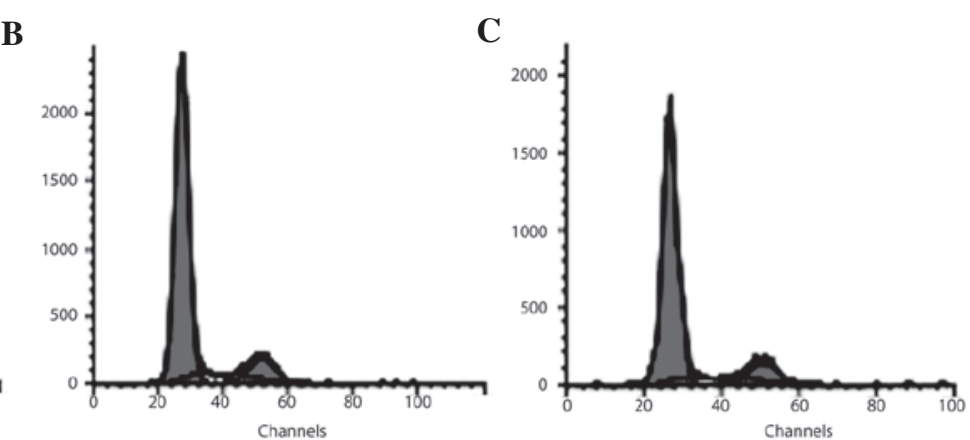

E

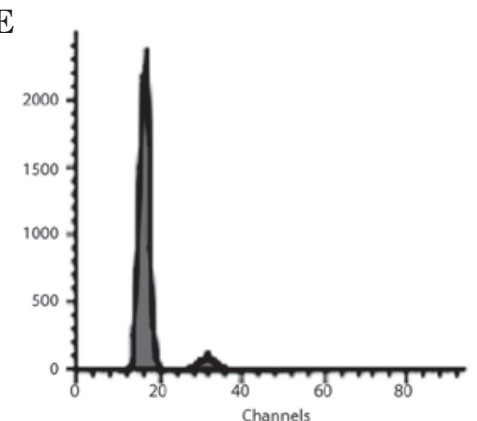

Figure 4. Effects of AZA on the cell cycle of MSCs derived from the bone marrow of Sprague-Dawley rats. The MSCs at passage 4 were treated with AZA at different concentrations for $72 \mathrm{~h}$. Cell cycle analysis was performed using flow cytometry. (A) Blank control. (B) Treated with 0.05 mg/ml of AZA. (C) Treated with $0.10 \mathrm{mg} / \mathrm{ml}$ AZA. (D) Treated with $0.20 \mathrm{mg} / \mathrm{ml} \mathrm{AZA.} \mathrm{(E)} \mathrm{Treated} \mathrm{with} 0.30 \mathrm{mg} / \mathrm{ml}$ AZA. AZA, azathioprine; MSCs, mesenchymal stem cells.

cells. MSCs also provide a variety of growth factors to support tissue repair and reconstruction (2). In addition, MSCs are likely to communicate with other cells to exert immunomodulating effects on countering the mucosal damage induced by the chronic inflammation of IBD (2). All these suggest an essential role of MSCs in IBD treatment.

As MSCs potentially contribute to the repair of the mucosa in IBD (5), the importance of optimizing the microenvironment for the colonization and differentiation of MSCs needs to be emphasized (22). The majority of MSCs were distributed into the lung after they were intravenously injected into the experimental animals (23-25). Therefore, it is assumed that only a small fraction of the MSCs are able to eventually colonize to the injured intestinal mucosa in the IBD scenario. Factors, including the intestinal epithelium, the cytokines produced by the epithelium and drugs are able to affect the proliferation and differentiation of MSCs, which directly affect the outcome of MSC transplantation. 
AZA is a purine analog immunosuppressive drug. There are few studies investigating the effect of AZA on the proliferation and differentiation of MSCs. Lazebnik et al (26) reported that $72.7 \%$ of patients with ulcerative colitis who were receiving 5-aminosalicylate, prednisone, AZA and methotrexate responded to MSC transplantation in a two-year follow-up study. Nevertheless, they did not ascertain whether AZA was associated with the treatment failure for the remaining $27.3 \%$ of patients. Duijvestein et al (21) demonstrated in an in vitro study that the phenotype and function of MSCs were not affected by the therapeutic concentrations of drugs generally used in IBD treatment, including AZA. In the present study, we demonstrated that there were no significant effects of AZA on the cell proliferation, cell cycle and apoptosis of the BMSCs derived from SD rats when the concentration was $<0.10 \mathrm{mg} / \mathrm{ml}$. The proliferation of the BMSCs was inhibited by $>66 \%$ and the percentage of apoptotic BMSCs increased while the concentration of AZA exceeded $0.20 \mathrm{mg} / \mathrm{ml}$ and the treatment lasted for $72 \mathrm{~h}$ compared with the blank control group. In the $0.30 \mathrm{mg} / \mathrm{ml}$ AZA group, apoptosis of the BMSCs reduced, however more necrotic cells were observed at $72 \mathrm{~h}$. These results suggest that AZA was able to induce apoptosis of the BMSCs at certain concentrations with prolonged exposure time, which lead to cell death of the BMSCs at high doses. We also demonstrated that the percentage of BMSCs increased in the G0-G1 phase and decreased in the $S$ phase when the concentration of AZA exceeded $0.20 \mathrm{mg} / \mathrm{ml}$ with prolonged exposure time. Those in the G2-M phase also decreased at $72 \mathrm{~h}$ in the $0.30 \mathrm{mg} /$ ml AZA group. These results indicated that AZA affects the proliferation of BMSCs through the synthesis of DNA and the mitosis of cells.

In the last decade, biological therapy was introduced as a novel strategy for IBD treatment, however the response rate was only $38-68 \%$ with certain cases flaring up following termination of the use of biological therapy (17). This is associated with the development of antibodies against the biological agents and this problem has yet to be resolved $(27,28)$. Therefore, gastroenterologists and investigators are seeking novel strategies for the treatment of IBD. MSC transplantation is one of these resolutions. Duijvestein et al (21) demonstrated that the therapeutic concentration of infliximab did not affect the survival, phenotype and function of human MSCs in vitro. Our data demonstrated that infliximab $(0.10-0.40 \mathrm{mg} / \mathrm{ml})$ had a minimal effect on the cell proliferation, apoptosis and cell cycle of the MSCs derived from the SD rats. These results provide useful information on the interaction between the two treatment methods of IBD in vitro. The in vivo effects of infliximab on the biological features of MSCs and on the homing of MSCs to the injured mucosa in the inflammatory microenvironment are yet to be determined. Further studies are also necessary to investigate the immunoregulatory effect of MSCs in vivo, particularly on improving the autoantibody-related events of biological treatment in IBD.

In conclusion, AZA was able to affect the proliferation and induce apoptosis, or cause death of MSCs at high doses. Infliximab has no observed effect on the cell proliferation, apoptosis and cell cycle of MSCs derived from the SD rats in vitro.

\section{Acknowledgements}

This study was supported by the Beijing Medical Award Foundation, China Medical Hand in Hand Project (Y. Zhong, no. XHYSGZZSDX-001) and the National Natural Science Foundation of China (Y.Zhong, no. 81370499). This study was also supported by the Yat-sen Scholarship for Young Scientist (Y. Lin).

\section{References}

1. Beyer Nardi N and da Silva Meirelles L: Mesenchymal stem cells: isolation, in vitro expansion and characterization. Handb Exp Pharmacol 174: 249-282, 2006.

2. Li YP, Paczesny S, Lauret E, et al: Human mesenchymal stem cells license adult $\mathrm{CD} 34^{+}$hemopoietic progenitor cells to differentiate into regulatory dendritic cells through activation of the Notch pathway. J Immunol 180: 1598-1608, 2008.

3. Powell DW, Mifflin RC, Valentich JD, Crowe SE, Saada JI and West AB: Myofibroblasts. II. Intestinal subepithelial myofibroblasts. Am J Physiol 277: C183-C201, 1999.

4. Lazebnik LB, Konopliannikov AG, Kniazew OV, et al: Use of allogeneic mesenchymal stem cells in the treatment of intestinal inflammatory disease. Ter Arkh 82: 38-43, 2010 (In Russian).

5. Gonzalez-Rey E, Anderson P, Gonzalez MA, Rico L, Büscher D and Delgado M: Human adult stem cells derived from adipose tissue protect against experimental colitis and sepsis. Gut 58: 929-939, 2009.

6. Suarez-Almazor ME, Spooner C and Belseck E: Azathioprine for treating rheumatoid arthritis. Cochrane Database Syst Rev 4: CD001461, 2000.

7. Sandborn WJ: Azathioprine: state of the art in inflammatory bowel disease. Scand J Gastroenterol (Suppl 225): 92-99, 1998.

8. Patel AA, Swerlick RA and McCall CO: Azathioprine in dermatology: the past, the present, and the future. J Am Acad Dermatol 55: 369-389, 2006.

9. Rumbo C, Emerick KM, Emre S and Shneider BL: Azathioprine metabolite measurements in the treatment of autoimmune hepatitis in pediatric patients: a preliminary report. J Pediatr Gastroenterol Nutr 35: 391-398, 2002.

10. Abu-Shakra M and Shoenfeld Y: Azathioprine therapy for patients with systemic lupus erythematosus. Lupus 10: 152-153, 2001.

11. Tiede I, Fritz G, Strand S, et al: CD28-dependent Rac1 activation is the molecular target of azathioprine in primary human $\mathrm{CD}^{+}$ T lymphocytes. J Clin Invest 111: 1133-1145, 2003.

12. Waters OR and Lawrance IC: Understanding the use of immunosuppressive agents in the clinical management of IBD. Curr Drug Targets 12: 1364-1371, 2011.

13. Chevaux JB, Peyrin-Biroulet L and Sparrow MP: Optimizing thiopurine therapy in inflammatory bowel disease. Inflamm Bowel Dis 17: 1428-1435, 2011.

14. Oh CJ, Das KM and Gottlieb AB: Treatment with anti-tumor necrosis factor alpha (TNF-alpha) monoclonal antibody dramatically decreases the clinical activity of psoriasis lesions. J Am Acad Dermatol 42: 829-830, 2000.

15. Maini R, St Clair EW, Breedveld F, et al: Infliximab (chimeric anti-tumour necrosis factor alpha monoclonal antibody) versus placebo in rheumatoid arthritis patients receiving concomitant methotrexate: a randomised phase III trial. ATTRACT Study Group. Lancet 354: 1932-1939, 1999.

16. Braun J and Sieper J: Ankylosing spondylitis. Lancet 369: 1379-1390, 2007.

17. Yamamoto-Furusho JK: Current and future biological treatments in inflammatory bowel disease. In: Gene Therapy Applications. Kang C (ed). InTech, Rijeka, pp363-374, 2011.

18. Van den Brande JM, Braat H, van den Brink GR, et al: Infliximab but not etanercept induces apoptosis in lamina propria T-lymphocytes from patients with Crohn's disease. Gastroenterology 124: 1774-1785, 2003.

19. Efron PA and Moldawer LL: Cytokines and wound healing: the role of cytokine and anticytokine therapy in the repair response. J Burn Care Rehabil 25: 149-160, 2004.

20. Böcker W, Docheva D, Prall WC, et al: IKK-2 is required for TNF-alpha-induced invasion and proliferation of human mesenchymal stem cells. J Mol Med (Berl) 86: 1183-1192, 2008. 
21. Duijvestein M, Molendijk I, Roelofs H, et al: Mesenchymal stromal cell function is not affected by drugs used in the treatment of inflammatory bowel disease. Cytotherapy 13: 1066-1073,2011.

22. Zan $\mathrm{H}$ and Zhong YQ: The progress of mesenchymal stem cells in the treatment of inflammatory bowel disease. New Medicine 4: 211-215, 2011 (In Chinese).

23. Fischer UM, Harting MT, Jimenez F, et al: Pulmonary passage is a major obstacle for intravenous stem cell delivery: the pulmonary first-pass effect. Stem Cells Dev 18: 683-692, 2009.

24. Schrepfer S, Deuse T, Reichenspurner H, Fischbein MP, Robbins RC and Pelletier MP: Stem cell transplantation: the lung barrier. Transplant Proc 39: 573-576, 2007.

25. Lee RH, Pulin AA, Seo MJ, et al: Intravenous hMSCs improve myocardial infarction in mice because cells embolized in lung are activated to secrete the anti-inflammatory protein TSG-6. Cell Stem Cell 5: 54-63, 2009.
26. Lazebnik LB, Kniazev OV, Konopliannikov AG, et al: Allogeneic mesenchymal stromal cells in patients with ulcerative colitis: two years of observation. Eksp Klin Gastroenterol 11: 3-15, 2010 (In Russian).

27. Baert F, Noman M, Vermeire S, Van Assche G, D'Haens G, Carbonez A and Rutgeerts P: Influence of immunogenicity on the long-term efficacy of infliximab in Crohn's disease. N Engl J Med 348: 601-608, 2003.

28. Sagynbaeva VÉ, Lazebnik LB, Kniazev OV and Efremov LI: Antibodies to infliximab and antigens HLA I-II class as the witnesses of immune response to the biological treatment of inflammatory bowel disease. Eksp Klin Gastroenterol 12: 7-14, 2011 (In Russian). 